\title{
Boosting Regulations Legislation Reliefs Regarding Environmental Management Systems in the Framework of EMAS and ISO 14001: Case Study of Cyprus
}

\author{
Loizia Pantelitsa $^{a}$, Voukkali Irene ${ }^{a}$, Antonis A. Zorpas ${ }^{b}$ \\ ${ }^{a}$ ENVITECH (Environmental Technology) Ltd, Institute of Environmental Technology and Sustainable Development, \\ Department of Research - Development, Paralimni, Cyprus \\ ${ }^{b}$ Cyprus Open University, Faculty of Pure and Applied Sciences, Environmental Conservation and Management, \\ Laboratory of Chemical Engineering and Engineering Sustainability Nicosia, Cyprus
}

\begin{abstract}
Environmental Management Systems (EMS) defining a list of requirements that can help organizations to improve their environmental performance. The most common well-known standards are ISO 14001 and EMAS, which both are in a voluntary base. Beside the National Legislation in Cyprus (N.761/2001) there is no any relief document that introduced EMAS Regulation (EC) N. 1221/2009. However, there is an increasing pressure on firms, from a number of different sources (i.e. global market requirements, legislative indirect pressure, customer's satisfaction etc.), to engage in environmental management initiatives. The aim of this study is to evaluate the incentives as well as the difficulties that Small Medium Enterprises (SMEs) which are located in Cyprus and other European countries (i.e. Italy, Chez Republic and Slovenia) that are facing during the implementation of EMS. The preliminary results indicated that in the case of Cyprus, there are not any specific regulatory reliefs besides some funding programs to convince SMEs to implement and maintain EMAS as well as ISO 14001. On the other hand, in several EU countries there are some more solids measures to encourage SMEs to adopt EMAS.
\end{abstract}

Keywords: EMAS legislation, ISO 14001 legislation, BRAVER.

\section{Introduction}

EMS has become one of the main tools, which commonly used from any kind of SMEs and Organizations in order to handle, control, maintain, monitor and assess their environmental aspects and impacts that caused to the environment from their activities [1]. EMS represents the part of an organization's management system, which helps organizations to control several and occasionally significant environmental issues (e.g., use of natural resources, air pollution, water consumption and pollution, soil and subsoil consumption, waste production and treatment, etc.) [2]. The most commonly applied standards of EMS are ISO 14001 (international level) and Eco-Management and Audit Scheme (EMAS) (European level) [3]. Any organization wants to develop an EMS, has to evaluate, control and then monitor its environmental impacts, set targets to reduce impacts and then establish a strategy on how to reach those targets $[4,5,6]$. Campos [7] emphasized that all the relevant activities from any organization affect several environmental issues and EMS must reflect as review in order to identified and control all those impacts. According to Singh et al. [8] the compliances of regulatory is consider to be one of the most important and significant reasons regarding the implementation of EMS. Moreover, the involvement of human resource management [9] and to training educational activities, as well as awareness improvement [10] are very important. Market share [11] and the competitiveness [12] are consider to be the main reasons that any SME proceed with EMS certification in the framework of ISO 14001 or EMAS. In addition, the external image and reputation of the certified EMS (ISO 14001 or EMAS) is an effective response to customer's pressures [5]. There are several difficulties to be solved before the implementation of EMS from any SMEs and organizations,

\footnotetext{
${ }^{*}$ Corresponding author. Tel.: +357-22411936

E-mails: antonis.zorpas@ouc.ac.cy, pantelitsaloiza@envitech.org, irenevoukkali@envitech.org

(C) 2018 International Association for Sharing Knowledge and Sustainability

DOI: $10.5383 /$ ijtee.17.01.003
} 
and the relevant costs (especially to the very SMEs with less than 5 employees) to be the most important one [13]. Additionally, the size of the companies [14], the industrial sectors [8] and other business variables [15] must also take into account. Hence, changes in local and international environmental legislation [16] and supply chain dynamics [17] constitute significant barriers of the implementation of EMS. Finally, the difficulty of quantifying the economic benefit of the EMS could become a real obstacle in adopting these voluntary standards [18].

\subsection{Environmental management system ISO 14001}

ISO 14001 standard plays a leader role for the EMSs. It is an international standard provides specific requirements and guidelines to develop and maintain an effective EMS. This standard (approved in 1996, revised in 2004, and again in 2015) indicates specific set-up, in order to developed and maintain EMS aiming continual improvement in the framework of Deming cycle "plan-do-check-act" $[19,20]$. It is a management system that supports organizations to control their environmental impacts, and issues to reduce waste and pollution, to prevent environmental liabilities and also to increase their competitiveness and corporate responsibility image [21, 22]. The main goal of the ISO 14001 is to provide a holistic, strategic approach in the framework of the development of EMS in order to help any SME to establish their environmental policy, plans, and actions. ISO 14001 is also applicable to all sizes and types of organization [15]. As one of the most widely used voluntary approaches, in 2015 worldwide 319,496 organizations had received ISO 14001 certification and 346,189 organizations in 2016 [23].
Beside EMS, Al Awadhi et al., [24] indicated that Clean Development Mechanism (CDM) is also a tool to assist development countries to reach their reductions emission targets in order to contribute to sustainable development. CDM could be useful tool and work in parallel with any EMS as CDM works under Article 12 of the Kyoto protocol to assist developing countries in achieving their emission reduction targets. CDM mainly focused on the reduction of energy, reduction of $\mathrm{CO} 2$ emissions as well as to introduced more renewable energy projects.

\subsection{Eco-Management and Audit Scheme System (EMAS)}

The European Union Council (EC) adopted EMAS in June 1993. Companies have opened it to volunteer participation since April 1995. A new version of this standard was published in November 2009 (EC e No 1221/2009 of the European Parliament and Council) [25]. In European, organizations are encouraged by the European Union to adopt EMAS in order to assure legal compliance and improve environmental performance $[3,26]$, as well as to reduced pollution, waste production, energy consumption and efficiency and natural resources [1]. Figure 1, presents the official statistics of the European EMAS Helpdesk- Evolution of Organizations and Sites from April 2010 until April 2017 [27]. EMAS is a European regulation while ISO 14001 is an international standard issued and subjected to periodic updated by ISO [1]. The requirement of ISO 14001 is considered to be essential part of EMAS. However, EMAS takes into account additional elements to support organizations that continuously improve their environmental performance. Table 1 presents the main differences between EMAS and ISO 14001 [28].

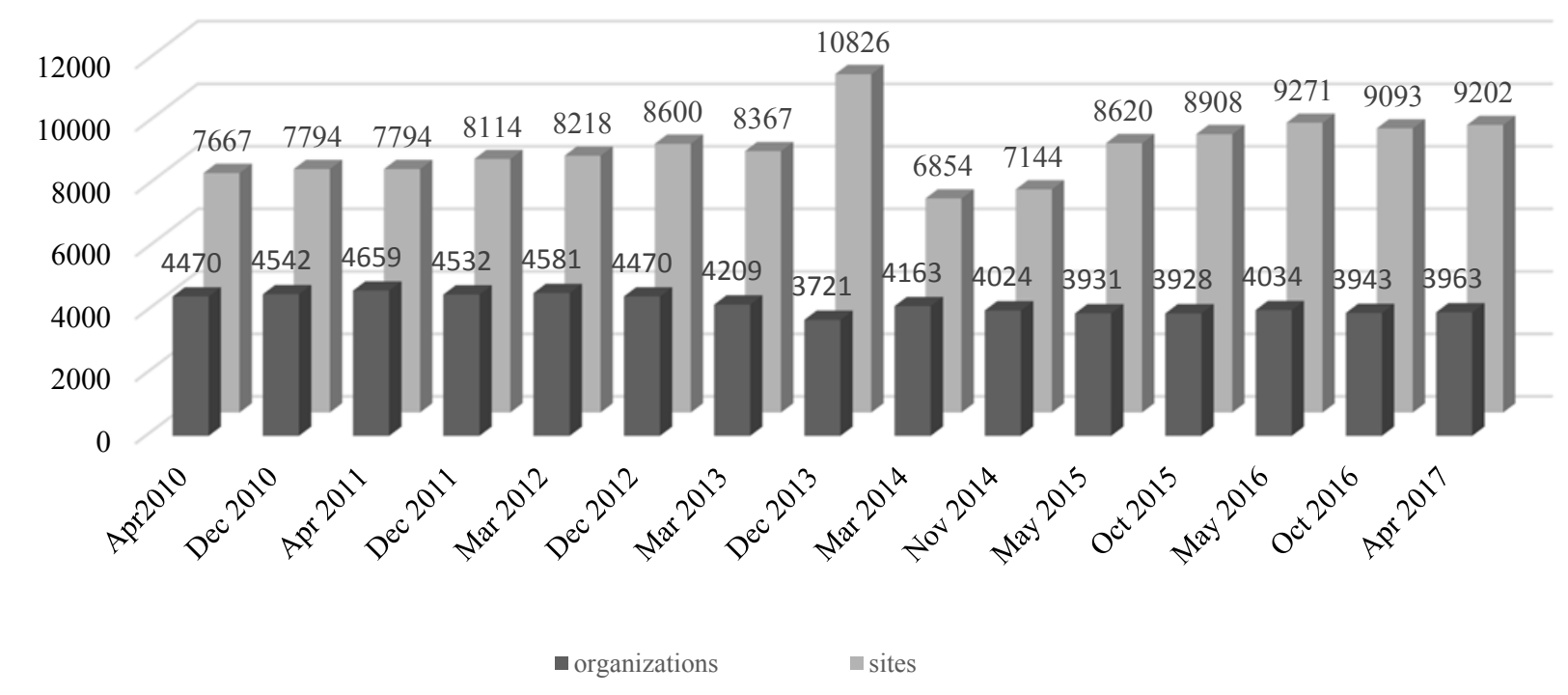

Fig. 1. European EMAS register organizations and sites [27] 
Table 1. Main differences between EMAS and ISO 14001

\begin{tabular}{|c|c|c|}
\hline Elements & EMAS & ISO 14001 \\
\hline Legal status & European Legislation (EC) No 1221/2009 & International, commercial standard under private law \\
\hline Participation & - $\quad$ Voluntary & Voluntary \\
\hline Goal and objective & $\begin{array}{l}\text { - Continual improvement of environmental } \\
\text { performance of the organization }\end{array}$ & - $\quad$ Continual improvement of the EMS \\
\hline Environmental aspects & $\begin{array}{l}\text { - Comprehensive initial environmental review of the } \\
\text { current status of activities, products and services }\end{array}$ & 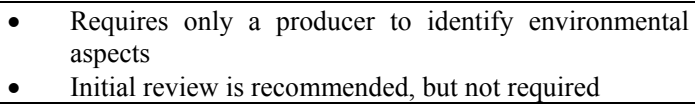 \\
\hline Employees involvement & $\begin{array}{ll}\text { - } & \begin{array}{l}\text { Active involvement of employees and their } \\
\text { representatives }\end{array}\end{array}$ & $\begin{array}{l}\text { - Not required (ISO } 14001 \text { and EMAS) both foresee } \\
\text { training for employees }\end{array}$ \\
\hline Suppliers and contractors & - Influence over suppliers and contractors is required & $\begin{array}{l}\text { - Relevant procedures are communicated to suppliers and } \\
\text { contractors }\end{array}$ \\
\hline External communication & $\begin{array}{l}\text { - } \text { Open dialogue with external stakeholders is required } \\
\text { - } \\
\text { External reporting is required on the basis of a } \\
\text { regularly published environmental statement }\end{array}$ & $\begin{array}{ll} & \text { Dialogue with external stakeholders not required } \\
- & \text { External reporting is not required }\end{array}$ \\
\hline $\begin{array}{ll}\text { Internal environmental } \\
\text { auditing }\end{array}$ & $\begin{array}{l}\text { - Environmental Management System audit } \\
\text { - } \\
\text { Performance audit to evaluate environmental } \\
\text { performance } \\
\text { - Environmental compliance audit }\end{array}$ & $\begin{array}{l}\text { - Includes only the Environmental Management System } \\
\text { audit of the requirements of the standard }\end{array}$ \\
\hline Verifier / Auditor & $\begin{array}{l}\text { - Environmental verifiers are accredited/licensed and } \\
\text { supervised by governmental bodies } \\
\text { - Independence of the environmental verifier is } \\
\text { required }\end{array}$ & $\begin{array}{l}\text { - Certification bodies are accredited through a national } \\
\text { Accreditation body } \\
\text { - Independence of the auditor is recommended }\end{array}$ \\
\hline Audits & $\begin{array}{l}\text { - Inspection of documents and site visits to be carried } \\
\text { out according to Regulation } \\
\text { Check for improvement of environmental } \\
\text { performance Data from environmental statement } \\
\text { needs to be validated }\end{array}$ & $\begin{array}{l}\text { - No certification rules in standard (other standards for } \\
\text { auditing and certification) } \\
\text { - Check of Environmental Management System } \\
\text { performance, but no frequency specified or required }\end{array}$ \\
\hline Derogations for SMEs & $\begin{array}{l}\text { - Extension of verification intervals from three to four } \\
\text { years } \\
\text { Updated environmental statement needs to be } \\
\text { validated only every two years (instead of every year) } \\
\text { - Environmental verifier takes into account special } \\
\text { characteristics of SMEs }\end{array}$ & - $\quad$ No derogations foreseen \\
\hline $\begin{array}{l}\text { Official registration by } \\
\text { authorities }\end{array}$ & $\begin{array}{l}\text { - } \begin{array}{l}\text { Publicly accessible register records each organization } \\
\text { - } \\
\text { Each registered organization receives a registration } \\
\text { number }\end{array} \\
\end{array}$ & - $\quad$ No official register \\
\hline Logo & - $\quad$ Yes & not needed \\
\hline
\end{tabular}

\subsection{Case Study for Cyprus}

In Cyprus, there are 85 EMAS certified organizations (since 2016) among them two is from public sector, i.e. the Cyprus Department of Environment and the Ministry of Defence [27]. Regarding EMAS regulation (1221/2009 / EC) Cyprus has been harmonized with the National Legislation with the Law 10 (I) / 2012 and the responsible authority for the registration process about the organizations who intends to implement EMAS is the Department of the Environment. Cyprus is participating (from 2016-2019) in a Life project BRAVER (LIFE15/ENV/IT/000509 - Boosting Regulatory Advantages Vis à vis Emas Registration), under the objective to increase the adoption of measures of regulatory relief to support EMAS adoption in participating countries and regions. Currently, there are not any specific measures besides some funding programs to convince and motivate organizations and other interested parties to implement and maintain EMAS. The main existing funding program in place, is from the Department of Environment of Cyprus aiming to cover in each SME $70 \%$ of the initiative consultancy cost to adopt EMAS, including verification and validation but the maximum amount (that SME can received) cannot exist the $€ 2,500$. Although, all organizations and SMEs can apply to this funding scheme, this scheme in not available continuously. Alternative, funding is also provided from the
Human Resource Development Authority of Cyprus (HRDA) in order to cover the needed training regarding employee's environmental education $(\sim 80 \%$ of the total training cost and limited to $€ 5,000$ per training program to be reimbursed from any SME and organization). Periodically, Cyprus Tourist Organization (CTO) provides grants to the hospitality industry of the Island (mainly the tourism sector) either for renovations or for new facilities. Hotels that implements any EMS during the evaluation process of their application form receives extra points should they have adopt any EMS certification.

Regulatory policy has already made a significant contribution to economic development and societal well-being. Economic growth and development have been promoted through regulatory policy's contribution to structural reforms, liberalisation of product markets, international market openness, and a less-constricted business environment for innovation and entrepreneurship. Regulatory policy has supported the rule of law through initiatives to simplify the law and improve access to it, as well as improvements to appeal systems. Increasingly, it supports quality of life and social cohesion, through enhanced transparency which seeks out the views of the regulated, and programmes to reduce red tape for citizens [29]. Regulatory relief policies could be essential part among public governance and enterprises as well as transparency and citizens engagements [29]. Moreover, beside regulatory policy reliefs Crowdfunding 
has recently emerged as an innovative method of financing ventures that fall outside the purview of traditional capital markets as well as is consider an alternative network for financing a project that uses an online platform to solicit generally small contributions from numerous participants (SMEs or Organizations) [30].

\section{Material and Methods}

The approach of the present study was designed to gather feedback and suggestions from certified organizations with EMAS and/or ISO 14001 in order to identify the relief measures and the results regarding EMS implementation. For this purpose, eight interview protocols were developed for each relevant main player: Top and environmental manager of EMAS registered organizations, environmental manager of ISO 14001 organizations, trade associations, regulatory authorities, environmental verifiers, EMAS competent body and EMAS experts. The structure of the questionnaire consists of five parts per Table 2 and these are dealing with:

a) Introductory which is aimed to explain the objectives and the procedure of the interview and also the professional background of the interviewees,

b) EMAS adoption and integration include main findings and quotation on key aspects reported by the interviewee. Thes quotations guarantee the accuracy, consistency and clarity of each reply.

c) Effectiveness of regulatory reliefs in which the organizations describe if they are aware of the regulatory reliefs (linked to EMAS) and if they are benefiting from it.

d) Suggestions for new regulatory relief measures. Organizations suggested a new regulatory relief measures in order to introduced and motivate more organizations to implement EMAS or other EMS.

e) Reporting obligations. This part focuses on the identification of the potential of EMAS to facilitate the verified reporting obligations towards authorities.

As for the sample to interview, the stakeholder's involvement was achieved by several means including: (i) interviews with at least 3 EMAS certified organizations, (ii) interviews with at least 2 ISO 14001 certified organizations, (iii) interview with at least 1 public administration, involved in the adoption of the measure selected, (iv) interview with one consultant. Table 3 summarized the profile relating to the interviewees organizations. Interviews were held face-to-face discussion with all the environmental managers of the organizations and the results presented in the Deliverable A1.3. These represents as evidences from Case Studies and Policy Recommendations for considering EMAS registration - BRAVER (LIFE15 ENV/IT/000509). This aims at summing up major evidences emerging from Case Studies in particular policy recommendations for national and local authorities that have to include regulatory relief and incentives in both new and existing legislation [31].

\section{Results and Discussion}

Most of the interviewees were aware of the regulatory reliefs measures especially the funding programs from HRDA and the
Department of Environment. These funding programs were covered some of the costs regarding the implementation, verification and certification of the EMAS as well as for the training schedule. The interviewees also indicate the reasons that SMEs implement EMAS and/or ISO 14001. Flourmill, adopt EMAS due to requirements of the market and to post their competition. For the public authority the motives were to reduce their activities environmental impact, to achieve their environmental goals and to demonstrate to others (Organizations and SMEs) that is easy to apply. One additional reason for Winery to adopt EMAS is to follow the market trends and the emphasize of their company policy on environmental awareness. As for ISO 14001 certified organizations the main reasons that they implement the standard were: Its correlation with ISO. the requirements from market, especially the demand for an EMS for the products exportation as Bakery A mentioned. In hotel sectors, particularly the five-stars category, the adopt ISO 14001 is primarily to emphasize their reduction of their environmental impact and increase environmental awareness to their staff and customers. Secondarily, is in response to the tourists who explicitly ask to adopt EMS and mainly ISO 14001. For Bakery (B) the main reasons were the market demands and compliance with the legislation additional to the improvements of their corporate image and credibility. Taking into account, the lack of the regulatory reliefs measures in Cyprus the Interviewees identified the need of more regulatory reliefs mainly focused on cost benefits (to increase the amount of funding support) as well as to minimized the audits period from public authorities. Table 4 summarizes the proposed regulatory reliefs from each interviewee. The same research focused on the identification of regulatory reliefs from the adoption of EMAS, was also carried out by the other participants (two universities from Italy, one public sector, and one SME from Czech Republic, additional to one Research center from Slovenia). The interviewees from Italy were aware of the existing regulatory relief measures and, in some cases, they had also benefitted from them. However, none of the interviewees declared that they adopt EMS certification/registration aiming of gaining these regulatory reliefs measures. The decision to adopt certified systems was mainly driven by the willingness to guarantee proper regulation compliance, risk prevention and reduction and in order to increase reputational gains or even by the specific request from the Public Authority. Regarding the survey audit from Czech Republic, SMEs were aware from the existing regulatory relief measures. They appreciate how the exception from the obligation to provide financial security enables those to save financial resources, time and human resources as they do not need to carry out detailed environmental risk assessment. Although the existing regulatory reliefs were challenged, it was not the driving factor for the implementation of EMS. Additionally, the results indicated that (experts and verifiers opinions) the current measures are not motivating factors to adopt EMAS. Most of the interviewed from Slovenia emphasized that awareness and promotional of EMS (ISO 14001 and EMAS) were poor and they are unaware of the benefits of regulatory reliefs. At the national level, the adoption of EMAS from SMEs remain in low profile. Higher institutions do not promote the adoption of EMAS and there are no events or conferences organized on this topic. From this perspective, the level of institutional support for EMAS organizations is unsatisfactory. The interviewees strongly recommend that the government should support and encourage businesses to adopt EMS. Regarding the effectiveness of the investigated measures it is important to mention that the most of the proposed measures are common to all the participating countries. The simplification of environmental inspections and licensing procedures, as well as economic facilities are the main measures proposed to 
convince them to adopt and implement EMS. In addition, the interviewees propose a better cooperation with the authorities, especially those relating to environmental issues. Finally, more funds and promotion campaigns are supported, in order to spread EMAS and ISO 14001. Table 5 summarizes some of the regulatory reliefs measures proposed by the interviewees [31].

Table 2. Template to report interview (sample of questions)

\begin{tabular}{|c|c|}
\hline PART & QUESTIONS \\
\hline \multirow{3}{*}{ Introductory part } & Name of the interviewee, function/ role in the organization \\
\hline & Name of the organization / economic sector \\
\hline & Year of EMAS adoption \\
\hline \multirow{2}{*}{$\begin{array}{l}\text { EMAS Adoption and } \\
\text { Integration }\end{array}$} & $\begin{array}{l}\text { Does environmental management actively support the organization in its daily practices, as well as in the achievement } \\
\text { of its strategic objectives, business goals and institutional relations? }\end{array}$ \\
\hline & Could you identify the main reasons/drivers that led you to implement EMS EMAS registered? \\
\hline \multirow{2}{*}{$\begin{array}{l}\text { Effectiveness of regulatory } \\
\text { reliefs }\end{array}$} & Are you aware of any regulatory reliefs (linked to EMAS) your organization is currently benefiting from? \\
\hline & Can you describe the effects of the regulatory reliefs your company has benefited from? \\
\hline $\begin{array}{l}\text { Suggestions for new } \\
\text { regulatory relief measures }\end{array}$ & $\begin{array}{l}\text { What innovations should be introduced, in the short and mid-term, in the context of national or EU regulation in order } \\
\text { to provide regulatory reliefs for EMAS organizations? }\end{array}$ \\
\hline \multirow[b]{2}{*}{ Reporting obligations } & What are the reporting and/or monitoring obligations that organisations see as most relevant? Most burdensome? \\
\hline & $\begin{array}{l}\text { In your opinion, which aspects of the EMAS regulation/environmental statement can be changed/improved in order } \\
\text { to fulfil multiple additional reporting requirements? }\end{array}$ \\
\hline
\end{tabular}

Table 3. Interviewing Organizations profile

\begin{tabular}{|c|c|c|c|}
\hline Type of organization & $\begin{array}{c}\text { EMAS certified } \\
\text { ogranization }\end{array}$ & $\begin{array}{c}\text { ISO 14001 certified } \\
\text { ogranization }\end{array}$ & $\begin{array}{c}\text { Number of years since } \\
\text { the first certification }\end{array}$ \\
\hline Flourmills & $\checkmark$ & & 7 \\
\hline Public authority & $\checkmark$ & & 3 \\
\hline Winery & $\checkmark$ & $\checkmark$ & 10 \\
\hline Bakery (A) & & $\checkmark$ & 10 \\
\hline Bakery (B) & & $\checkmark$ & 3 \\
\hline Hotel & & & \\
\hline
\end{tabular}

Table 4. Regulatory relief proposals

\begin{tabular}{|c|c|c|}
\hline Organization & & Regulatory relief proposals \\
\hline Department of Environment & $\begin{array}{l}\text { Public Authority } \\
\text { EMAS register } \\
\text { organization }\end{array}$ & 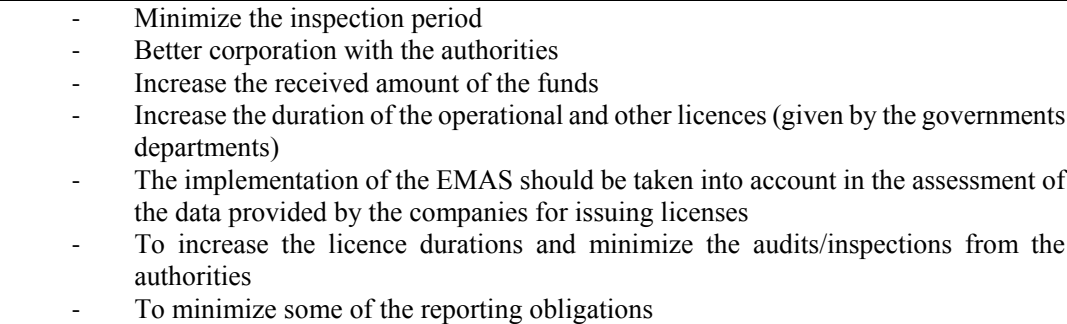 \\
\hline Flourmill & $\begin{array}{l}\text { EMAS register } \\
\text { organization }\end{array}$ & $\begin{array}{l}\text {-Regarding our company, changes should be taken in the process, regarding waste } \\
\text { production and the management cost of them. So, it will be useful if there are } \\
\text { regulatory reliefs in this direction" }\end{array}$ \\
\hline Winery & $\begin{array}{l}\text { EMAS register } \\
\text { organization }\end{array}$ & $\begin{array}{ll}- & \text { Increase the financial support } \\
- & \text { Minimized the Inspections by government departments }\end{array}$ \\
\hline Bakery A & $\begin{array}{l}\text { ISO } 14001 \\
\text { certified } \\
\text { organization }\end{array}$ & $\begin{array}{l}\text { - "Except the increase of the funding supports in short and long term I think that it will } \\
\text { be very important if the authorities corporate with the verifiers for taking data about } \\
\text { the certified organization with aiming less controls and reports requirements" }\end{array}$ \\
\hline Bakery $B$ & $\begin{array}{c}\text { ISO } 14001 \\
\text { certified } \\
\text { organization }\end{array}$ & $\begin{array}{ll}- & \text { Increase of the funding support } \\
- & \text {-Possibility for less environmental inspections from the stakeholders }\end{array}$ \\
\hline Hotel & $\begin{array}{l}\text { ISO } 14001 \\
\text { certified } \\
\text { organization }\end{array}$ & $\begin{array}{ll}\text { - } & \text { Use EMAS as a condition (or preferred option) from tourist agents like ISO } 14001 \\
\text { - } & \text { Linking EMAS with the evaluation awards given in hotels } \\
\text { - } & \text { Use EMAS as a condition for obtaining licence for water waste disposal (and other } \\
\text { related licences }\end{array}$ \\
\hline
\end{tabular}


Table 5. Regulatory relief measures proposed by each participant country

\begin{tabular}{|c|c|}
\hline Country & Regulatory reliefs measure \\
\hline $\begin{array}{l}\text { Chez } \\
\text { Republic }\end{array}$ & $\begin{array}{ll}- & \text { Simplification of environmental inspections } \\
- & \text { Simplified reporting } \\
- & \text { Tax relief } \\
- & \text { Public procurement } \\
- & \text { EMAS as a condition for obtaining licence - e.g. operation of waste "collective system", remediation/decontamination } \\
& \text { activities } \\
- & \text { Decrease administrative burden (the environmental statement provided once in three years) } \\
\text { - } & \text { Provide a media campaign to increase the awareness of EMAS }\end{array}$ \\
\hline Cyprus & $\begin{array}{ll}\text { - } & \text { Minimize the inspection } \\
\text { - } & \text { Better corporation with the authorities } \\
\text { - } & \text { Increase the amount of the funds } \\
\text { - } & \text { Increase the duration of the licences (given by the governments departments) } \\
\text { - } & \text { The implementation of the EMAS should be taken into account in the assessment of the data provided by the companies } \\
\text { - } & \text { for issuing licenses } \\
\text { - } & \text { to increase the licence durations and minimize the audits/inspections from the authorities } \\
& \text { to minimize some of the reporting obligations }\end{array}$ \\
\hline Slovenia & $\begin{array}{ll} & \text { reduction the inspection } \\
- & \text { simplification of administrative procedures } \\
- & \text { priority treatment and less complex procedures for renewal and obtaining environmental protection permit for EMAS } \\
\text { organization } \\
\text { - } & \text { reduction of taxes, fees, network charges } \\
- & \text { green public procurement } \\
\text { - } & \text { lower bank guarantees (waste sector) } \\
\text { better cooperation with the authorities provide a promotional activity (EMAS EASY) for small organizations in term of } \\
\text { training }\end{array}$ \\
\hline Italy & $\begin{array}{l}\text { - Innovations in national regulation should aim at strengthening the trust between registered organisations and institutions, } \\
\text { therefore enhancing flexibility in the renewal or modifications of environmental integrated authorization and avoiding } \\
\text { excessive bureaucratization. } \\
\text { - Effective regulatory reliefs should focus on simplifying and facilitating external monitoring duties as a reward to self- } \\
\text { monitoring activities. Innovations should therefore aim at reducing monitoring costs or facilitating organizations by } \\
\text { substituting mandatory monitoring plans with the results of self-monitoring activities. } \\
\text { - Policy makers should develop further regulatory reliefs for ISO } 14001 \text { organizations, almost to the same level of the ones } \\
\text { for EMAS-registered organizations because, if compared to ISO 14001, adopting EMAS requires only small additional } \\
\text { efforts. } \\
\text { - } \quad \text { Reduction of public institutions inspection and valorise the external audit. } \\
\text { - Fiscal incentives measures can be introduced in the context of national legislation in order to provide regulatory reliefs } \\
\text { for EMAS organizations. } \\
\text { About new measures that can increase the number of EMAS registration, the interviewee suggests "the reduction of time } \\
\text { for permitting" and "more certainty on the time of issuing permits". }\end{array}$ \\
\hline
\end{tabular}

The evaluation indicated that the implementation of EMS presents several difficulties, especially the implementation and maintain cost, which its considered to be one of the main issues that the management team takes into consideration when they should take a decision to adopted or not an EMS [32]. Other barriers refer to the lack of awareness's and the limited corporation with authorities, primarily those with environmental responsibilities.

Additionally, a conclusion arise from the research refers to the different needs and expectations (interms of EMAS/ISO 14001 promotion and increase) of the different Countries involved in the Project, and to the replicability of the measures addressed. Compared with the other Countries, Italy has in fact an advanced and mature context, whereas Cyprus, Czech Republic and Slovenia are still in their early stages, both in terms of number of registrations/certifications and of existing regulatory reliefs. In this sense, it can be said that they still need institutional efforts to address the lack of awareness and knowledge of the schemes that still characterize their contexts [31].

\subsection{Regulatory reliefs, incentives or other simplification measures in other countries}

Several member states have recognized the usefulness of regulatory reliefs, incentives or other simplification measures in order to promote and encourages organizations to implement EMS. Those reliefs are categorized in four typologies of policy and promotional support measures: legal measures, financial measures, informational measures and marketing and promotional measures. Figure 2 depicts a general overview of the different types of EMAS support measures implemented in the member states between 2010 and 2015 [33]. Its shows that states supported EMAS through informational and marketing promotional instruments more than through legal and financial ones. Over $80 \%$ of countries implemented instruments from informational and the marketing/promotional categories, while 
$55 \%$ had financial instruments. Only $35 \%$ of Member States reported legal instruments promoting EMAS [33].

Examples of some EMAS promotion measures are given below. France exempts EMAS registered organizations under the European Industrial Emissions Directive (IED 2010/75 EU) from environmental inspections only if they have demonstrated legal compliance in their environmental statements. However, French organizations with ISO 14001 (but not EMAS) must, still subjected to inspections every 10 years. Furthermore, France permits the EMAS environmental statement to replace part of an obligatory Corporate Social Responsibility (CSR) report. Moreover, competent bodies have provided smaller financial incentives to organizations.

The most common initiative is waiving or reducing EMAS registration fees, for organizations with EU Ecolabel that also register EMAS (20\% discount on their annual EU Ecolabel fee) [33]. In 2011, as part of a general effort to streamline and simplify permitting processes and regulations, the Greek government passed two laws, i.e. 4014/2011 and 3982/2011, which targeting organizations in the manufacturing sector. Under the 3982/2011Law, manufacturing and related sectors that manage hazardous waste and are EMAS registered receive a $50 \%$ reduction in the required insurance fee for environmental remediation.
Additionally, under the 4014/2011Law [35] the duration of the Environmental License is extended by four years (14 years in total) in the case of manufacturing units that are EMAS registered and by two years (12 years in total) in the case of units that apply ISO 14001 or an equivalent EMS [33,34]. Regarding the tourist sector if any hotel has a certified EMS receives an extra bonus (200 points) in the stars rating from Greek National Tourism Organization (GNTO) which helps the hotels to upgrade or maintain its existing hotel star rating category [36]. Germany has the highest number of EMAS registrations across the EU, with 1,223 organisations and 2,047 sites. Both the German federal government and the individual states, provide to EMAS registered organisations and those organisations interested in implementing EMAS, a variation of financial and other support measures. Direct federal funds are available to SMEs, covering $50 \%$ in Western Germany and $75 \%$ in Eastern Germany of the consultation costs. Moreover, Germany voted the EMAS Privilege Act (EMAS Privilegierungs Verordnung) as a law detailing the legal privileges exclusive to EMAS registered organisations. According to this act, registered organizations are excluded from their duty of disclosure or appointing a dedicated person and from presenting reports on the organisation emissions, given that these criteria are already covered by the EU scheme [37].

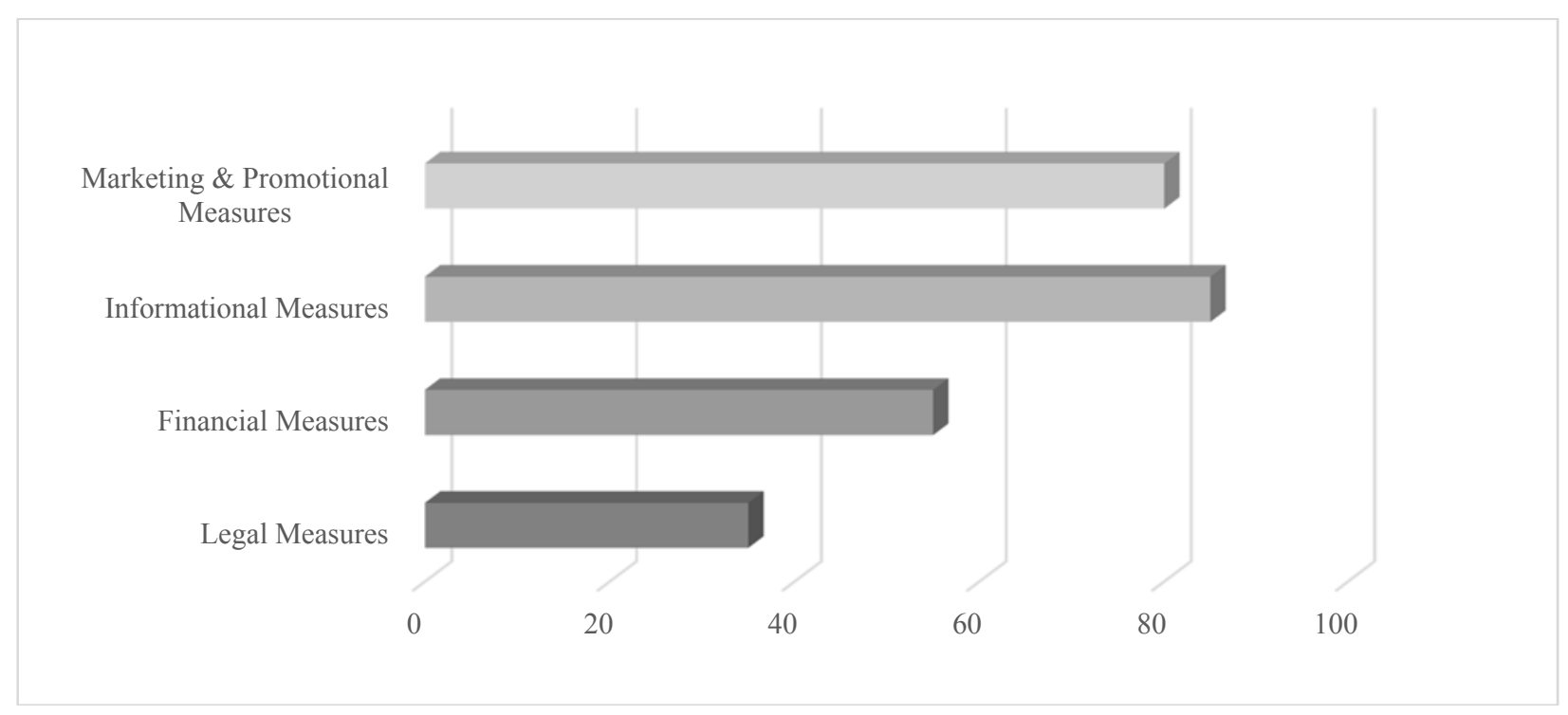

Fig. 2. Percentage of member states reporting EMAS support instrument (2010-2015) [30]

\section{Conclusion}

The implementation of an EMS consists an important component for the organizations to reduce the environmental impacts from their activities. However, organizations are often unable to understand the critical factors for implementation and adoption of EMS, mainly due to a lack of awareness and reliefs measures. Comparing several participant countries, Italy has in fact an advanced and mature context, whereas Cyprus, Czech Republic and Slovenia are still at their early stages as far as the number of registrations/certifications and the existing regulatory reliefs. In Cyprus the weaknesses arise mainly due to the lack of education, information and environmental awareness of stakeholders. Also, there is lack of awareness among the policy makers who are the responsible authority for adopting the regulatory reliefs. Finally, there is a lack of information about the EMAS and its benefits or framework of any incentives. The case study shows that the existing regulatory reliefs in Cyprus were inadequate to convince organizations to adopt and implement EMAS. The organizations who already adopt the EMAS neither took advantage of the existing reliefs, nor those ISO 14001 certified organization had the intention to certified with EMAS. One obvious reason that they did not think they will have extra benefits. All interviewers reported the necessity for more effective regulatory and financial reliefs. Summarizing, considering the implementation of measures reliefs from the other participant countries, Cyprus government and all the stakeholders must apply a combination of legal and financial instruments with effective promotion and information strategies in order to help organisations and to gain the maximum benefit from EMAS and other EMS. 


\section{Acknowledgments}

This research is co-funded from the European Commission and consist a Life project with the Acronym, BRAVER (LIFE15/ENV/IT/000509 - Boosting Regulatory Advantages Vis à vis Emas Registration), and who aim to increase the adoption of measures of regulatory relief to support EMAS adoption in participating countries and regions.

\section{References}

[1] Testa, F., Rizzi, F., Daddi, T., Gusmerotti, N.M., Frey, M., Iraldo, F., 2014. EMAS and ISO 14001: the differences in effectively improving environmental performance. J. Clean. Prod. 68, 165 173

[2] Ruskko, M., Sablik, J., Marková, P., Lach, M., Friedrich, S., 2014. Sustainable development, quality management system and environmental management system in Slovak republic. Proc. Eng. 69, 486-491.

[3] Mazzi, A., Toniolo, S., Gatto, S., De Lorenzi, V., Scipioni, A. 2017. The combination of an Environmental Management System and Life Cycle Assessment at the territorial level. Environmental Impact Assessment Review. 63, 59-71.

[4] Daddi, T., Testa, F., Frey, M., Iraldo, F. 2016. Exploring the link between institutional pressures and environmental management systems effectiveness: an empirical study. J Clean. Prod. 183 (3), 1239-1248

[5] Djekic, I., Rajkovic, A., Tomic, N., Radovanovic, R. 2014 Environmental management effects in certified Serbian food companies. J Clean. Prod. 76, 196-199.

[6] Heras, I., Arana, G., 2010. Alternative models for environmental management in SMEs: the case of Ekoscan vs. ISO 14001. J. Clean. Prod. 18 (8), 726 - 735.

[7] Campos, L.M.S., 2012. Environmental management systems (EMS) for small companies: a study in Southern Brazil. J. Clean. Prod. 32, 141 - 148.

[8] Singh, M., Brueckner, M., Padhy, P.K., 2014. Insight into the state of ISO14001 certification in both small and medium enterprises and industry best companies in India: the case of Delhi and Noida. J. Clean. Prod. 69, 225 - 236.

[9] Paille, P., Chen, Y., Boirla, O., Jin, J., 2014. The impact of human resource management on environmental performance: an employee-level study. J. Bus. Ethics 121, 451- 466.

[10] Pereira-Moliner, J., Claver-Cortes, E., Molina-Azorín, J.F., Tarí, J.J., 2012. Quality management, environmental management and firm performance: direct and mediating effects in the hotel industry. J. Clean. Prod. 37, 82 - 92

[11] Feng, T., Cai, D.,Wang, D., Zhang, X., 2016. Environmental management systems and financial performance: the joint effect of switching cost and competitive intensity. J. Clean. Prod. 113 , 781- 791

[12] Singh, N., Jain, S., Sharma, P., 2015. Motivations for implementing environmental management practices in Indian industries. Ecol. Econ. 109, 1-8.

[13] Alonso-Paulí, E., Andre, F., 2015. Standardized environmental management systems as an internal management tool. Res. Energy Econ. 40, 85 - 106
[14] Puig, M.,Wooldridge, C., Michail, A., Darbra, R.M., 2015. Current status and trends of the environmental performance in European ports. Environ. Sci. Policy 48, 57 - 66.

[15] To, W.M., Lee. P.K.C. 2014. Diffusion of ISO 1400 environmental management system: global, regional and country-level analyses. Journal of Cleaner Production. 66, $489-$ 498.

[16] Zhu, Q., Cordeiro, J., Sarkis, J., 2013. Institutional pressures, dynamic capabilities and environmental management systems: investigation the ISO 9001 e environmental management system implementation linkage. J. Environ. Manag. 114, 232 - 242.

[17] Gonzales-Benito, J., Lannelongue, G., Queiruga, D., 2011. Stakeholders and environmental management systems: a synergistic influence on environmental imbalance. J. Clean. Prod. $19,1622-1630$.

[18] Yang, M.G.M., Hong, P., Modi, S.B., 2011. Impact of lean manufacturing and environmental management on business performance: an empirical study of manufacturing firms. Int. J. Prod. Econ. 129, $251-261$

[19] ISO, 2015. Environmental Management Systems - Requirements with Guidance of Use (ISO 14001:2015). International Standard Organization, Geneva.

[20] Voukkali, I., Loizia, P., Pociovalisteanu, D.M., Zorpas, A.Z. 2017. Barriers and Difficulties Concerning the Implementation of an Environmental Management System in a BakeryConfectionary Industry in Cyprus for 8 Years. Environ. Process. $4,263-275$

[21] Alrazi, B., de Villiers, C., Staden, C.J. 2015. A comprehensive literature review on and the construction of a framework for, environmental legitimacy, accountability and proactivity. J. Clean. Prod. 102, $44-57$.

[22] Shah, K.U. 2015. Choice and control of international join venture partners to improve corporate environmental performance. J. Clean. Prod. 89, 32 - 40.

[23] ISO, 2016. The ISO Survey of Management System Standard Certifications 2016. (ISO 14001:2015).

[24] Al Awadhi, S., Abbas, Z., Mezher, T. 2017. Analyzing sustainable development impact of Large-Scale clean development mechanism projects on host countries. Int. J. Thermal Environ. Eng. 14(2), 153-161.

[25] Campos, M.S..L, Aparecida de Melo Heizen, D, Verdinelli, M.A, Cauchick Miguel, P.A. 2015. Environmental performance indicators: a study on ISO 14001 certified Companies. Clean. Prod. 99, 286 - 296.

[26] Heras-Saizarbitoria, I., Arana, G., Boiral, O., 2015. Exploring the dissemination of environmental certifications in high and low polluting industries. J. Clean. Prod. 89, 50-58.

[27] European Commission, 2017. European EMAS register organizations and sites. Available from: http://ec.europa.eu/environment/emas/emas_registrations/statisti cs_graphs_en.htm [Accessed, Sep 27 2017].

[28] COM, 2011. EMAS and ISO 14001: complementarities and differences http://ec.europa.eu/environment/emas/pdf/factsheets/EMASiso1 4001 high.pdf [Accessed, Oct 23 2017]. 
[29] OECD, 2010. Regulatory policy and the road to sustainable development growth, https://www.oecd.org/regreform/policyconference/46270065.pd f [Accessed, Jan 15 2018]

[30] Renwick J.M., Mossialos E. 2017. Crowdfunding our health: economic risks and benefits. Soc. Sci. Medic. 191, 48-56.

[31] DELIVERABLE A.1.3: Evidences from Case Studies and Policy Recommendations for considering EMAS Registration. 2017. BRAVER (LIFE 15 ENV/IT/000509).

[32] Massoud, AM., Fayad, R., El-Fadel, M., Kamleh, R. 2010 Drivers, barriers and incentives to implementing environmental management systems in the food industry: a case of Lebanon. J. Clean. Prod. 18, 200-209.

[33] European Commission, 2015. EMAS Promotion \& Policy Support in the Member States. Compendium 2015. Available from:

http://ec.europa.eu/environment/emas/pdf/other/EMAS_Compe ndium_2015.pdf [Accessed, Oct 24 2017].
[34] Law 3982/2011 simplifying the licensing of business parks (previously industrial zones) Available from: http://www.elinyae.gr/el/item_details.jsp?cat_id=777\&item_id= $\underline{8986}$ [Accessed, Oct 23 2017].

[35] Law 4014/2011 (G.G. 209A/2001) "Environmental licensing for projects and activities, regulation of arbitrary constructions by reference to the creation of environmental balance and other competence provisions of the Ministry of Environment" Available from: http://www.ypeka.gr/Default.aspx?tabid=804\&language=el-GR [Accessed, Nov 2 2017].

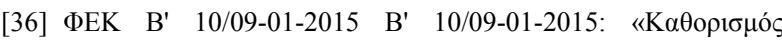

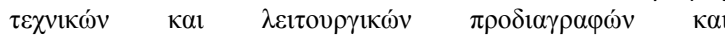

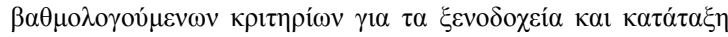
$\alpha v \tau \omega ́ v \sigma \varepsilon \kappa \alpha \tau \eta \gamma о \rho i ́ \varepsilon \varsigma \alpha \sigma \tau \varepsilon \dot{\rho} \omega v\rangle$

[37] European Commission, 2016. Analyzing the success drivers of EMAS in selected Member States. Three Case Studies. Available from: $\quad$ https://publications.europa.eu/en/publication-detail//publication/7e5a23aa-aa54-11e6-aab7-01aa75ed71a1 [Accessed, Oct 26 2017]. 